Коефіцієнт установчої площі наближається до своїх максимальних значень для магазинів економ-класу невеликої площі, де безліч дешевих товарів повинні мати високу оборотність для досягнення фінансової ефективності.

В цілому завантаженість торгових залів обладнанням залежить від рівня доходу цільових покупців: чим вище рівень доходу, тим більше вільного простору і менше обладнання в залі; чим нижче рівень доходу, тим більше торгового обладнання та товару представлено в залі.

\title{
Лiтература:
}

1. Тютюнник Я. С. Аналіз розміщення АЗС на автомобільних дорогах I категорії // Вісник Національного транспортного університету. К. : НТУ, 2013. Вип. 28. С. 472-476.

2. Шалай В.В. Проектирование и эксплуатация нефтебаз и АЗС : учебное пособие / В.В. Шалай. - Омск: Изд-во ОмГТУ, 2010. - 296 с.

3. Волгушев А.Н. Автозаправочные станции. Оборудование. Эксплуатация / А.Н. Волгушев, А.С. Сафонов, А.И. Ушаков. - СПб.: ДНК, 2001. - $176 \mathrm{c}$.

4. Коршак А.А. Нефтебазы и АЗС : учебное пособие / А.А. Коршак, Г.Е. Корабейников, Е.М. Муфтахов. - Уфа: Дизайн полиграф сервис, 2006. -416 с.

DOI https://doi.org/10.30525/978-9934-26-046-9-47

\section{ІНФОРМАЦІЙНІ ТЕХНОЛОГІЇ МОДЕЛЮВАННЯ ЖИТТЕВОГО ЦИКЛУ БУДІВЕЛЬ ТА СПОРУД}

\author{
Іванова Л. С. \\ кандидат технічних наук, доцент, \\ доиент кафедри нарисної геометрії та інженерної графіки \\ м. Київ, Украӥна
} Київський національний університет будівництва і архітектури

Життєвий цикл будь-якого архітектурно-будівельного об'єкту або споруди включає ряд етапів і регламентується законодавством, технологічними особливостями цього процесу та інформаційним наповненням. 
Визначення стадій (етапів) моделювання об'єкту будівництва і коректна постановка завдань, що розв'язуються на кожному етапі життєвого циклу об'єкту - основна частина документального забезпечення та прискорення повноцінного впровадження систем інформаційного моделювання (СІМ) у будівництві.

Таким чином основні задачі впровадження інформаційного моделювання наступні:

- визначення стадій життєвого циклу об'єкту будівництва;

- визначення принципів інформаційного моделювання об'єкту будівництва;

- розробка регламентів процесу інформаційного моделювання.

Життєвий цикл будівлі або споруди - період, протягом якого здійснюються інженерні вишукування, проектування, будівництво, консервація незавершеного будівництва, експлуатація, ремонт, реконструкція, капітальний ремонт, ліквідація будівлі або споруди. Проте для об'єкту будівництва робота з будівлею може тривати і після ії ліквідації, наприклад віртуально, якщо це пам'ятник архітектури або наукові дослідження, пов'язані з територією або об'єктом у будь-якій галузі.

Тому видається більш правильним використовувати для будівель, особливо в системах інформаційного моделювання (CIM), більш універсальне визначення життєвого циклу об'єкту або комплексу об'єктів: сукупність стадій, що охоплюють різні стани об'єкту: 3 моменту виникнення необхідності в такому об'єкті і до завершення роботи 3 ним. Після завершення життєвого циклу доцільним $є$ архівне зберігання інформаційної моделі.

За впровадження технології системи інформаційного моделювання (CIM) детальне визначення та формалізація етапів життєвого циклу об’єкту набуває особливої важливості.

Сфера будівництва раніше обмежувала себе застосуванням систем автоматизованого проектування (САПР) без географічної прив'язки інфраструктурних об'єктів. Зокрема сучасна система BIM (Building Information Modeling) також дає можливість охоплювати проектування, будівництво, експлуатацію, ремонт будівлі або іншої споруди без прив'язки до географічної моделі, географічного простору оточуючого середовища.

Модель ВIM передбачає використання інформаційного ресурсу [2], що містить інформацію про об'єкти капітального будівництва та пов'язану з ними інформацію відповідно до ії класифікації, що дозволяє однозначно ідентифікувати дані в єдиному інформаційному сере- 
довищі [3] управління життєвим циклом об'єктів капітального будівництва.

Однак ситуація змінюється 3 тих пір, як ГІС почала створювати моделі даних, що підтримують як геометричні, так і ієрархічні потреби, які можуть враховувати внутрішню і зовнішню інфраструктуру. Геоінформаційні системи, або коротко ГІС, забезпечує збір, зберігання, обробку, аналіз і відображення геопросторових та інформаційних даних, а також отримання на їх основі знань про оточуюче середовище для створення об'єктів архітектури. Геопросторові дані - це дані, які ідентифікують географічне місце розташування і властивості природних або штучно створених об'єктів, а також їх межі на Землі.

Комплексна система інформаційного моделювання (CIM) має базуватися на якісно новому і технологічно підпорядкованому рівні організації взаємодії учасників інвестиційно-будівельної діяльності, що передбачає перехід від управління документами до управління даними, оптимізацію кількості та термінів проходження адміністративних процедур в рамках підготовки землевпорядної, містобудівної, проектної документації; будівництва, введення об'єкта в експлуатацію, державного кадастрового обліку та державної реєстрації об'єктів нерухомості; створення єдиної державної галузевої цифрової платформи управління життєвим циклом об'єктів капітального будівництва, що забезпечує накопичення і обмін даними, їх достовірність і актуальність на всіх стадіях життєвого циклу.

Наприклад, до початку будівельних робіт ГІС може виконувати важливу роль у виборі ділянки під забудову і інтеграції даних протягом усього процесу, можливість вибору найкращих рішень, які забезпечують максимальний життєвий цикл інфраструктури за умови найменших витрат. ГІС розробляються з метою вирішення наукових $\mathrm{i}$ прикладних задач з моніторингу екологічних ситуацій, раціонального використання природних ресурсів, а також для інфраструктурного проектування, міського та регіонального планування, для прийняття оперативних заходів в умовах надзвичайних ситуацій та інше.

СІМ за умови ефективної інтеграції ВIM і ГІС може забезпечити оптимальне і якісне моделювання всього життєвого циклу об'єкта 3 урахуванням розвитку, модернізації і впровадження нових технологій в майбутньому.

Системне об'єднання можливостей ВIM-технологій і моделей ГІС [4] надають можливість на принципово новому рівні проектувати, будувати і експлуатувати сучасні будівлі і споруди, здійснювати моніторинг їх безпеки. Питання безпеки пов'язані $з$ життєвими циклами 
будівлі, споруди і території його розташування, з зношенням інженерних, транспортних мереж та споруд і систем комунікації будівель, 3 необхідністю актуалізувати комунікації щодо сучасних ресурсозберігаючих технологій. Система інформаційного моделювання повинна забезпечувати контроль основних дестабілізуючих факторів в процесі будівництва і експлуатації та своєчасний ремонт і модернізацію.

BIM (Building Information Modeling) і ГІС (Геоінформаційна система) є двома найважливішими цифровими технологіями, інтеграція яких може забезпечити революційний прорив у сфері цифрового забезпечення життєвого циклу об'єктів будівництва, міського планування, інфраструктури довкілля [4]. I нарешті забезпечити найважливіше - довгострокове перспективне управління життєвим середовищем, включаючи зайнятість громадян, аналіз стабільності, готовність до катастроф, можливості експлуатаційних і управлінських напрямів застосування, наукових досліджень у різних галузях існування людства, професійна підготовка фахівців [1], тощо.

\section{Література:}

1. Іванова Л.С. Завдання нарисної геометрії та інженернографічної підготовки фахівців в концепції впровадження ВІМ технології в будівництві. Прикладна геометрія та інж. графіка. К: КДТУБА, 2020, Вип.98. - С. 48-56

2. Концепція впровадження ВIM - Будівельного Інформаційного Моделювання в Україні. Ukrainian BIM Community. BIM-UABTGConcept-ZZ-012720.pdf

3. ISO 19650-2:2018, IDT. Організація та оцифрування інформації щодо будівель та споруд включно з будівельним інформаційним моделюванням (BIM). Управління інформацією з використанням будівельного інформаційного моделювання. Частина 2. Етап будівництво (проект, перша редакція)

4. В.П. Куприяновский, С.А. Синягов, Д.Е. Намиот, Ю.В. Куприяновская. Экономические выгоды применения комбинированных моделей ВІМ-ГИС в строительной отрасли. Обзор состояния в мире. International Journal of Open Information Technologies ISSN: 2307-8162 Vol. 4. No. 5. 2016. 